\title{
Strategi Peningkatan Kompetensi Pegawai Bank Perkreditan Rakyat (BPR)
}

\author{
Novi Intan Fandini (1) \\ Ni Nyoman Sunariani ${ }^{(2)}$ \\ Universitas Pendidikan Nasional ${ }^{(1)}$ \\ Universitas Pendidikan Nasional ${ }^{(2)}$ \\ novifandini07@gmail.com ${ }^{(1)}$ \\ nyomansunariani@undiknas.ac.id ${ }^{(2)}$
}

\begin{abstract}
The purpose of this study was to find out and analyze the strategy of increasing HR competency in the Rural Credit Banks (BPR) of Denpasar City. This study used qualitative research methods. The collection technique used in this study was using the method of interview, observation, and documentation study. Data analysis in this study uses data reduction, data display, and data conclusion drawing/verification. The results of this study indicate that the strategy of improving HR competencies and the quality of work of each employee can be obtained from the results of the implementation of education and training (training). This can be assessed from changes in attitudes of each employee, knowledge and skills of employees, and the emergence of new innovations that are useful for improving HR competencies, the motivations given by superiors at PT. BPR Bali Dananiaga which plays an important and maximum role in providing the best experience, so that it will improve the performance of employees in the agency. This research can be useful for the leadership of PT. BPR Bali Dananiaga in decision making and also as an important reference to choose the type of education and training (training) that is needed by employees so that what is obtained from the results of the implementation of education and training (training) can be applied in their respective workplaces.
\end{abstract}

Keywords: Strategy; Competency Enhancement for Human Resources; BPR 
Tujuan penelitian ini adalah untuk mengetahui dan menganalisis strategi peningkatan kompetensi SDM pada Bank Perkreditan Rakyat (BPR) Kota Denpasar. Penelitian ini menggunakan metode penelitian kualitatif. Teknik pengumpulan yang digunakan dalam penelitian ini adalah dengan menggunakan metode wawancara, observasi, dan studi dokumentasi. Analisis data dalam penelitian ini menggunakan data reduction, data display, dan data conclusion drawing/verification. Hasil penelitian ini menunjukkan bahwa strategi peningkatan kompetensi SDM dan kualitas kerja masing - masing pegawai di dapat dari hasil penyelenggaraan pendidikan dan pelatihan (diklat). Ini dapat dinilai dari perubahan sikap setiap karyawan, pengetahuan serta ketrampilan dari pegawai, serta munculnya inovasi - inovasi yang baru yang berguna untuk peningkatan kompetensi SDM, adanya motivasi - motivasi yang diberikan oleh atasan di PT. BPR Bali Dananiaga yang berperan penting dan maksimal dalam memberikan pengalaman yang terbaik, sehingga akan meningkatkan kinerja pegawai di instansi. Penelitian ini dapar bermanfaat bagi pihak pimpinan di PT. BPR Bali Dananiaga dalam pengambilan keputusan dan juga sebagai acuan penting untuk memilih jenis pendidikan dan pelatihan (diklat) yang sangat dibutuhkan pegawai sehingga apa yang diperoleh dari hasil penyelenggaraan pendidikan dan pelatihan (diklat) tersebut bisa dapat diterapkan di tempat kerja masing - masing.

\section{Kata kunci : Strategi; Peningkatan Kompetensi Sumber Daya Manusia; BPR}




\section{PENDAHULUAN}

Negara Indonesia kini telah memasuki pasar tunggal yang dikenal dengan nama Masyarakat Ekonomi Asean (MEA) yang dimulai sejak tahun 2015 hingga saat ini yang membuat persaingan dunia perbankan nasional semakin kompetitif (Darma 2019 dan Darma et.al, 2019). Dengan adanya pembentukan pasar tunggal ini memungkinkan negara - negara yang berada di kawasan Asia Tenggara menjual barang dan jasa dengan mudahnya (Juzer dan Darma, 2019). Aktivitas mengelola dan mengembangkan sumber daya manusia (SDM) merupakan hal yang penting dan strategis dalam manajemen SDM pada sebuah Bank Perkreditan Rakyat (BPR). Dalam hal ini strategi yang dimiliki oleh pimpinan BPR, tanpa pengelolaan SDM untuk menjalankannya, strategi tersebut bisa menjadi tidak bermakna (Darma, 2019).

Pengaturan manajemen bank yang efisien dan efektif (Ratih, 2015; Darma, 2004) mengatakan bahwa proses pengukuran kerja sering kali membutuhkan penggunaan bukti statistik untuk menentukan tingkat kemajuan suatu organisasi dalam meraih tujuannya. Bank Perkreditan Rakyat (BPR) merupakan salah satu bentuk LembagaKeuangan Mikro (LKM) yang bersifat formal, ditinjau dari sisi kelembagaan maupun tujuan pendiriannya. Dari fungsi manajemen SDM, kegiatan yang sangat kentara serta memiliki titit taut dalam memilih, mengelola dan mengembangkan SDM adalah pada aspek pembuatan atau evaluasi analisa jabatan; rekruitmen, seleksi dan penempatan; serta pengembangan SDM. (Marsuki, 2016; Widiari dan Darma, 2019) mengatakan bahwa strategi pengembangan atau peningkatan BPR yang applicable guna membantu mewujudkan BPR dapat menjadi Bank yang berperan penting dalam proses pembangunan ekonomi bangsa salah satunya penguatan Kelembagaan. Industri BPR diyakini tidak akan berkembang tanpa adanya upaya penguatan kelembagaan.

Dalam upaya meningkatkan kualitas kompetensi SDM, kebijakan yang telah ada selama ini dipandang sudah cukup memadai. Pada posisi pengambil keputusan, ditetapkan kewajiban bagi direksi untuk memiliki sertifikat dari lembaga sertifikasi professional dalam hal ini bernama Certif. Hal ini tidak sejalan dengan hasil penelitian yang kemukakan oleh Rozi Fadillah (2017) yang berjudul Pengaruh Kompetensi, Disiplin Kerja dan Lingkungan Kerja Terhadap Karyawan Pada Kantor Bank Kalsel Cabang Pembantu di Banjarmasin. Hasil dari penelitian adalah kompetensi sumber daya manusia di BNI Syariah Surakarta pada PT tingkat manajer baik, didukung oleh pendidikan tinggi, banyak pelatihan, serta pengalaman. Sedangkan pada level karyawan masih perlu banyak perhatian, karena tingkat pendidikan di sana masih rendah, masih sedikit pelatihan, dan pengalaman tidak memadai. Dengan kualitas kompetensi SDM yang memadai, diharapkan nantinya akan semakin meningkatkan kualitas 
pelayanan dan efisiensi kegiatan operasional BPR. Hal ini berlaku menurut (Tahaka, 2013; Rusmahadewi dan Darma, 2018) Pengukuran kinerja pada perusahaan memerlukan system pengukuran kinerja yang tidak hanya mengukur aspek keuangan tetapi juga mempertimbangkan aspek non keuangan (Premawati dan Darma, 2019).

Di kota Denpasar terdiri dari 13 BPR (Bank Perkreditan Rakyat). Dari 13 jumlah BPR di kota Denpasar, salah satunya PT. BPR Bali Dananiaga yang memiliki nilai NPL tertinggi dengan jumlah presentase 25\%. Dengan nilai Non Performing Loan (NPL) tinggi tersebut akan menyebabkan SDM dalam kredit kurang memiliki kompetensi yang baik. PT. BPR Bali Dananiaga juga masih kurang disiplin mengikuti Standar Operasional Prosedur yang dibuat oleh bagian kepatuhan kredit. Sehingga berdampak dalam menyalurkan kredit di masyarakat, hal ini mengakibatkan pendapatan perusahaan semakin menurun serta tingginya tingkat Non Performing Loan (NPL), yang berdampak pada kesehatan Bank. Presentase penyaluran kredit pada BPR Bali Dananiaga pada tahun 2016 sebanyak 16\%, 2017 sebanyak 34\%, dan 2018 sebanyak 25\%, jumlah presentase tersebut di peroleh dari hasil laporan publikasi PT. BPR Balidananiaga.

\section{Strategi Peningkatan Kompetensi SDM}

Menurut Sagala (2013) dan Utomo dan Darma (2020), strategi memiliki pengertian sebagai rencana yang mengandung cara komprehensif dan interatif yang dapat dijadikan pegangan untuk bekerja, berjuang dan berbuat guna memenangkan kompetisi. Strategi merupakan instrument manajemen yang ampuh dan tidak dapat dihindari, tidak hanya untuk survival dan memenangkan persaingan tetapi juga untuk tumbuh dan berkembang (Darma, 2018). Pada dasarnya yang dimaksud dengan strategi menurut Siagian (2018) dalam bukunya yang berjudul manajemen stratejik merupakan "rencana berskala besar yang berorientasi jangkauan masa depan yang jauh serta ditetapkan sedemikian rupa sehingga memungkinkan organisasi berinteraksi secara efektif dengan lingkungannya dalam kondisi persaingan yang kesemuanya di arahkan pada optimalisasi pencapaian tujuan dan berbagai sasaran yang bersangkutan.

\section{Kompetensi}

Setiap perusahaan tentunya membutuhkan orang-orang yang kompeten untuk memajukan perusahaannya (Darma, et.al., 2019). Dunia yang didominasi sektor jasa, pentingnya modal manusia tidak dapat dipungkiri. Untuk mendapatkan pengembalian atas investasi (Return On Investment) sumber daya fisik dan teknologi, perusahaan sangat 
tergantung pada kompetensi pekerja. Dalam lingkup yang luas, modal manusia yang di definisikan sebagai keterampilan, ketangkasan, dan pengetahuan kelompok orang, merupakan penentu utama pertumbuhan ekonomi saat ini. Oleh karena itu, perusahaan harus berani melakukan upaya pengembangan kompetensi secara sistematis. Perspektif yang pertama menggambarkan kompetensi dari sudut pandang organisasi, yang mana kompetensi digambarkan sebagai pengetahuan, kepakaran dan kemampuan suatu organisasi yang dapat menjadikan organisasi tersebut memiliki keunggulan dibandingkan dengan para pesaingnya (Bali dan Darma, 2019). Pengertian kompetensi dalam hal ini terkonsentrasi pada kompetensi suatu organisasi sebagi suatu kesatuan dan menyeluruh. Sedangkan perspektif kedua mengarah pada kompetesi yang dimiliki individu. Dalam konteks ini, kompetensi diartikan sebagai karakteristik-karakteristik yang dapat diidentifikasi dari seseorang yang melakukan pekerjaannya secara efektif.

Karakteristik tersebut meliputi motif, sifat, keterampilan, citra diri, peranan sosial dan pengetahuan yang dimiliki. Williams dalam Carters (2011) mengemukakan bahwa individual competence describes what a person is capable of doing and includes a combination of motives and traits, the self-image of a person and his or her social role, skills and knowledge. Dari pendapat tersebut, nampak bahwa kompetensi individual dapat dilihat dari kemampuan seseorang untuk melakukan sesuatu pekerjaan dan termasuk didalamnya kombinasi motivasi dan sifatnya, citra diri atau peran sosialnya, keahlian dan pengetahuan. Berdasarkan uraian diatas kompetensi mempunyai makna yang sangat mendalam pada diri seseorang dengan suatu perilaku yang dapat di prediksi pada berbagai aspek keadaan. Suatu prediksi yang baik dan kurang yang digunakan tersebut dapat disusun sebagian besar untuk suatu pengembangan karir, peningkatan ketrampilan, pengetahuan dan penentuan kompetensi tersebut dibutuhkan guna untuk mengetahui efektivitas tingkat kinerja yang diharapkan perusahaan.

\section{Karakteristik Kompetensi}

Menurut Wibowo (2010), menyatakan bahwa kompetensi merupakan kemampuan atau karakteristik seseorang untuk bagaimana melaksanakan atau melakukan suatu pekerjaan atau tugas yang dilandasi atas keterampilan dan pengetahuan serta yang didukung oleh sikap kerja yang dituntut oleh pekerjaan tersebut. Terdapat 5 karakteristik atau komponen kompetensi yaitu:

1. Motif

2. Sifat

3. Konsep diri 
4. Pengetahuan

5. Keterampilan

\section{Dimensi Pokok Kualitas Pelayanan}

Menurut Parasuraman yang dikutip oleh Tjiptono (2011) terdapat lima dimensi pokok dalam kualitas pelayanan sebagai berikut:

1. Reliabilitas

2. Daya Tanggap

3. Jaminan

4. Empati

5. Bukti Fisik

SDM

SDM merupakan proses perencanaan, pengorganisasian, penyusunan pegawai, pengelolaan karir, pemberian kompensasi, evaluasi kinerja, dan hubungan ketenagakerjaan yang baik. Kunci SDM merupakan sebuah tindakan yang di ambil untuk dapat memberikan dan mempertahankan kinerja pegawai yang memadai di suatu perusahaan (Dewi dan Darma, 2017; Widiastra dan Darma, 2015; Yudiastra dan Darma 2015).

Berdasarkan berbagai pemahaman SDM diatas, dapat disimpulkan bahwa sumber daya manusia menurut penulis adalah pengelolaan sumber daya manusia sebagai asset yang utama, melalui penerapan fungsi manajemen maupun fungsi operasional sehingga tujuan organisasi yang telah ditetapkan dapat tercapai dengan baik. Sehingga selain pemahaman dari penulis, pemahaman dari para ahli tersebut menunjukkan demikian pentingnya sumber daya manusia dalam mencapai tujuan organisasi, ataupun pegawai.

\section{Kompetensi SDM}

Menurut Dewi dan Darma (2017); Widiastra dan Darma (2015); Yudiastra dan Darma (2015) dan Mangkunegara (2012) kompetensi sumber daya manusia adalah kompetensi yang berhubungan dengan pengetahuan, keterampilan, kemampuan dan karakteristik kepribadian atau inovasi baru yang dimiliki seseorang, dan dapat mempengaruhi secara langsung terhadap kinerjanya. Kompetensi sumber daya manusia memiliki pengetahuan yang lebih luas tentang visi, kemampuan mengantisipasi pengaruh perubahan, dan juga kemampuan memberikan pendidikan tentang sumber daya manusia. Sehingga dapat disimpulkan bahwa kompetensi sumber daya manusia adalah kemampuan yang dimiliki seseorang yang berhubungan dengan 
pengetahuan, keterampilan dan karakteristik kepribadian yang mempengaruhi secara langsung terhadap kinerjanya yang dapat mecapai tujuan yang diinginkan.

\section{Karakteristik Kompetensi Sumber Daya Manusia}

Dalam setiap individu seseorang terdapat beberapa karakteristik kompetensi dasar, yang terdiri atas berikut ini:

1. Watak (traits), yaitu yang membuat seseorang mempunyai sikap perilaku atau bagaimanakah orang tersebut merespon sesuatu dengan cara tertentu, misalnya percaya diri (self-confidence) , kontrol diri (self-control), ketabahan atau daya tahan (hardiness).

2. Motif (motive), yaitu sesuatu yang diinginkan atau diharapkan seseorang atau secara konsisten dipikirkan dan diinginkan yang mengakibatkan suatu tindakan yang diambil atau dasar dari dalam yang bersangkutan untuk melakukan suatu tindakan.

3. Bawaan (self-concept), yaitu sikap dan nilai-nilai yang dimiliki seseorang.

4. Pengetahuan (knowledge), yaitu informasi yang dimiliki seseorang pada bidang tertentu dan pada area tertentu.

5. Keterampilan atau keahlian (skill), yaitu kemampuan untuk melaksanakan tugas tertentu, baik secara fisik maupun mental.

\section{Kategori Kompetensi Sumber Daya Manusia}

Zwell (2019) memberikan lima kategori kompetensi ini, yang terdiri dari task achievement, relationship, personal attribute, managerial, dan leadership.

\section{Task achievement}

merupakan kategori kompetensi yang berhubungan dengan kinerja baik. Dimana akan meningkatkan kompetensi karyawan di perusahaan.

\section{Relationship}

merupakan kategori kompetensi yang berhubungan dengan komunikasi dan bekerja baik dengan orang lain dan memuaskan kebutuhannya, dimana hal ini akan menjadikan suatu perusahaan menjadi lebih baik lagi antar pegawai.

\section{Personal attribute}

merupakan kompetensi intrinsik individu dan menghubungkan bagaimana orang berpikir, merasa, belajar, dan berkembang, guna meningkatkan individualism dan karakter seseorang.

\section{Managerial}

merupakan kompetensi yang secara spesifik, dimana berkaitan dengan pengelolaan, pengawasan dan mengembangkan orang. Kompetensi manajerial berupa: memotivasi, 
memberdayakan, meningkatkan pengetahuan dan mengembangkan orang lain.

\section{Leadership}

merupakan kompetensi yang berhubungan dengan memimpin organisasi dan orang cara untuk mencapai maksud, visi, dan tujuan organisasi. Kompetensi berkenaan dengan berbagai macam leadership meliputi: kepemimpinan visioner, berpikir strategis, orientasi kewirausahaan, manajemen perubahan, membangun komitemen organisasional, membangun fokus dan maksud, dasar-dasar, dan nilai-nilai, dan produktivitas tinggi.

\section{Bank Perkreditan Rakyat}

BPR merupakan tempat yang dimana merupakan salah satu jenis bank perkreditan rakyat, yang dikenal banyak orang untuk melayani usaha kecil dan menengah dengan lokasi yang pada umumnya dekat dengan tempat masyarakat yang membutuhkannya, dan mudah dijangkau sesuai dengan kebutuhan (lokasi yang strategis). Menurut Permanasari dan Darma (2013); Arsiani dan Darma (2013); Adnyasuari dan Darma (2017), fungsi BPR tidak hanya sekedar menyalurkan kredit kepada para pengusaha mikro, kecil dan menengah, tetapi juga menerima simpanan dari masyarakat. Dalam penyaluran kredit kepada masyarakat menggunakan prinsip 3T, yaitu tepat waktu, tepat jumlah, dan tepat sasaran (Rusmahadewi dan Darma, 2018). Karena proses kreditnya yang relative cepat, persyaratan lebih sederhana, dan sangat mengerti akan kebutuhan. Adapun jenis yang diberikan oleh bank perkreditah rakyat yaitu, menghimpun dana masyarakat dalam bentuk deposito berjangka, tabungan dan atau bentuk lain yang dipersamakan dengan itu, dan memberikan kredit modal kerja, kredit investasi, maupun kredit konsumsi, (Kasmir,2010).

\section{Kinerja}

Perusahaan dalam merealisasikan tujuannya membutuhkan prestase dari faktor-faktor produksi yang terdapat dalam organisasinya, terutama dalam kinerja dari para karyawannya. Dalam kenyataannya salah satu masalah utama yang menjadi focus perhatian perusahaan adalah masalah kinerja produktivitas sumber daya manusia. Demi tercapainya tujuan perusahan, sebagai perusahaan yang mengharapkan kinerja yang terbaik dari keberhasilan perusahaan adalah karyawan yang mempunyai tingkat kinerja yang tinggi. Kinerja merupakan sesuatu yang dinilai dari apa yang dilakukan oleh seorang karyawan. Dalam kerjanya dengan kata lain, kinerja individu adalah bagaimana seorang karyawan melaksanakan pekerjaannya atau untuk kerjanya. Kinerja karyawan yang meningkat akan turut mempengaruhi atau 
meningkatkan prestasi organisasi sehingga tujuan organisasi yang telah ditentukan dapat dicapai. Kinerja merupakan suatu hasil pekerjaan yang dimana dapat dicapai seseorang sesuai persyaratan - persyaratan pekerjaan yang telah ditetapkan (job requirement). (Wiandari dan Darma, 2017; Dewi dan Darma, 2017; Widiastra dan Darma, 2015; Yudiastra dan Darma 2015).

\section{Kerangka Konseptual}

Penelitian ini merupakan penelitian deskriptif, dimana bentuk penelitian yang dilakukan ini untuk mengetahui nilai - nilai variabel yang mandiri, baik satu variabel atau lebih (independen) tanpa membuat suatu perbandingan atau yang menghubungkan dengan variabel lain serta hanya dapat meneliti tentang strategi kompetensi SDM untuk meningkatkan kinerja karyawan, yang dimana dengan adanya strategi kompetensi SDM dapat memberikan efek terhadap pengembangan kinerja karyawan. Penilaian kinerja dengan menggunakan strategi pemberdayaan kompetensi masih tergolong baru di Bali pada khususnya karena tidak banyak perusahaan yang menggunakan metode ini. Perbandingan hasil menggunakan metode penilaian kinerja perusahaan dalam hal ini BPR Bali Dananiaga tidak hanya diukur melalui satu sisi saja yaitu sisi keuangan pada umumnya tetapi juga dari sisi non keuangan. Sehingga dengan menggunakan metode ini akan lebih menggambarkan kondisi BPR secara keseluruhan. Penelitian ini menyajikan bagaimana penilaian kinerja dari PT BPR Bali Dananiaga dengan menggunakan strategi kompetensi Sumber Daya Manusia, sehingga nantinya bisa menjadi pilihan bagi perusahaan untuk mendidik karyawannya agar menjalankan tugas sesuai SOP. Dalam hal ini Strategi Kompetensi pemberdayaan Sumber Daya Manusia mengaitkan tata cara yang ada didalam suatu perusahaan yang pertama diawali dengan tujuan, visi, misi, rencana strategi dan pengukuran kinerja dalam keberhasilan perusahaan serta mengaitkan komponen kunci dari informasi menetapkan tujuan serta mencari untuk mengaitkan tujuan yang akan dicapai oleh perusahaan. Adapun kerangka konseptual yang digunakan dalam penelitian ini a adalah sebagai berikut : 


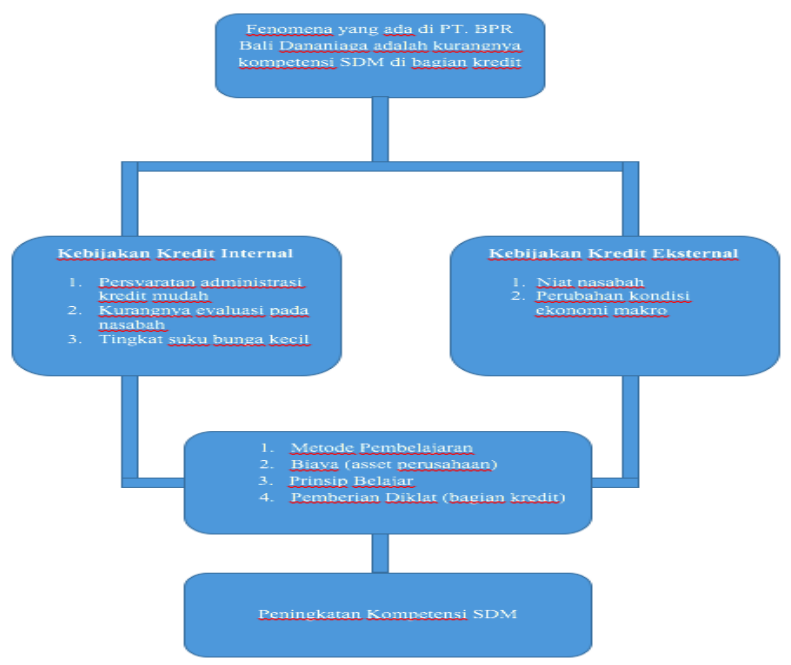

\section{METODE PENELITIAN}

Desain penelitian pada penelitian ini menggunakan pendekatan kualitatif dengan metode analisis deskriptif. Metode kualitatif dapat diartikan sebagai metode penelitian yang berdasarkan pada filsafat enterpretif, digunakan untuk meneliti pada kondisi objek yang alamiah (sebagai lawannya adalah eksperimen) dimana peneliti sebagai instrument kunci, teknik pengumpulan data dilakukan secara trianggulasi (gabungan), analisis data bersifat induktif atau kualitatif, dan hasil penelitian kualitatif lebih menekankan makna dari pada generalisasi (Darma, 2004). Dalam penelitian ini yang menjadi objek penelitian adalah salah satu organisasi yang bergerak dibidang jasa keuangan yaitu PT Bank Perkreditan Rakyat Bali Dananiaga Kantor Pusat yang terletak di Jl. Gatot Subroto Tim. No.332, Kesiman Petilan, Denpasar Timur, Kota Denpasar.

Penelitian ini menggunakan pengumpulan data dari sumber primier dan sumber sekunder. Data primer diperoleh langsung dari hasil wawancara kepada para informan yang dimana dianggap berpotensi dalam memberikan informasi yang relevan dan sebenarnya di lapangan, seperti Direktur, Para Pegawai Kredit, Kabag Kredit, Nasabah di PT. BPR Bali Dananiaga Institut yang pernah mengikuti pendidikan dan pelatihan. Sedangkan data sekunder pada penelitian ini merupakan data yang diambil dari instansi dengan permasalahan yang terjadi di lapangan. Untuk menggunakan data primer dan sekunder digunakan beberapa teknik pengumpulan data yaitu wawancara, observasi dan studi dokumentasi, dengan penentuan informan dilakukan dengan teknik purposive sampling, dimana pemilihan informan adalah menurut kriteria tertentu dan disesuaikan dengan topik penelitian.

Penelitian ini melakukan analisis data, terlebih dahulu memastikan apakah data yang ditemukan serta interpretasinya telah akurat atau belum. Teknik analisa data yang digunakan 
dalam penelitian ini adalah metode kualitatif. Menurut (Rully dan Poppy, 2016) Pendekatan kualitatif adalah pendekatan penelitian yang diarahkan untuk pencapaian tujuan memperoleh penjelasan yang luas, tentang fenomena yang ditetapkan sebagai objek penelitian dalam melihat keterkaitan antar variable lebih banyak menggunakan berpikir induktif (empiris). Dimana menurut Sugiono dalam Metode Penelitian Bisnis Pendekatan Kuantitatif, Kualitatif, Kombinasi dan R\&D (2017), trianggulasi dalam pengujian kredibilitas ini diartikan sebagai pengecekan data dari berbagai sumber dengan berbagai cara, dan berbagai waktu dari sumber yang sama.

\section{PEMBAHASAN}

Dari hasil penelitian yang dilakukan melalui proses wawancara dengan beberapa informan di PT. BPR Bali Dananiaga, maka ditemukan hasil penelitian yaitu Pendidikan dan Pelatihan (diklat) yang telah didapatkan oleh para pegawai maupun pejabat di PT. BPR Bali Dananiaga dirasakan sangat bermanfaat untuk peningkatan kompetensi dan kualitas kerja masing - masing pegawai. Adanya penyegaran informasi yang mereka terima baik itu yang menyangkut tentang aturan baru maupun ketentuan - ketentuan lainnya yang bermanfaat bagi instansi dan pegawai kedepannya. Peningkatan kompetensi melalui pendidikan dan pelatihan (diklat) yang mereka terima sehingga akan tercipta kebersamaan dari para pegawai, memunculkan semangat kerja, inovasi baru untuk memajukan PT. BPR Bali Dananiaga agar menjadi instansi perbankan terpercaya di masayarakat. Dengan adanya pendidikan dan pelatihan (diklat) melalui proses yang cukup panjang dalam peningkatan kompetensi ini, pegawai dapat memiliki pengetahuan dan keterampilan yang cukup baik dari sebelumnya. Hal ini berakibat terhadap pegawai agar dapat dijadikan sebuah pendorong terciptanya peningkatan kompetensi pegawai yang berkualitas.

\section{Pendidikan dan Pelatihan (diklat)}

Peningkatan kualitas, efisiensi suatu perusahaan (instansi) tidak hanya tergantung dari teknologi saja, modal (asset) perusahaan yang dimiliki serta bahan yang terbaik, tetapi semua itu tidak akan terwujud tanpa adanya peran serta kompetensi SDM yang mempunyai kualitas baik dan sangat produktif. Untuk mewujudkan kompetensi SDM yang berkualitas baik dan sangat produktif tersebut di perlukan adanya pendidikan dan pelatihan (diklat). Pendidikan dan pelatihan merupakan upaya untuk pengembangan atau peningkatan kompetensi SDM, yaitu untuk pengembangan atau peningkatan kemampuan pengetahuan dan kepribadian manusia. Pelaksanaan pendidikan dan pelatihan (diklat) di PT. BPR Bali Dananiaga di selenggarakan 
oleh Direktur dan Kabag setiap per divisi yang diikuti oleh para pegawai sesuai dengan masingmasing bidang pekerjaan yang ada di lingkungan PT. BPR Bali Dananiaga yang bertujuan guna untuk meningkatkan kompetensi SDM, menambah pengetahuan dan keterampilan, meningkatkan kualitas dan produktivitas, terciptanya loyalitas dan kerjasama yang solid antar pegawai yang ada di PT. BPR Bali Dananiaga.

Pendidikan dan pelatihan (diklat) dikemukakan oleh Notoatmodjo (2009), merupakan "upaya untuk mengembangkan sumber daya manusia, terutama untuk mengembangkan kemampuan intelektual dan kepribadian manusia." Untuk itu pendidikan dan pelatihan (diklat) dapat dikatakan adalah proses dan upaya untuk membentuk dan mengembangkan sumber daya manusia dengan menambah pengetahuan, ketrampilan, keahlian, dan prilakunya.

Terdapat beberapa penelitian terdahulu yang mendukung hasil penelitian ini seperti hasil penelitian oleh Meitaningrum et. al. (2013), menemukan bahwa efektivitas pendidikan dan pelatihan dalam meningkatkan kinerja pegawai Kabupaten Malang sudah efektif. Hasil penelitian lain oleh Tiara et al.(2015), menunjukkan bahwa pengembangan pegawai melalui program pendidikan dan pelatihan (diklat) di Dinas Pendidikan dan Kebudayaan Provinsi Bengkulu membawa suatu pengaruh positif, baik bagi pihak pegawai itu sendiri maupun instansi. Tesis ini ada perbedaan dengan hasil studi yang dilakukan oleh Handayani et. al. (2015), dari hasil penelitian ditemukan bahwa pelaksanaan diklat PIM tingkat III PNS angkatan 226 di BKD kabupaten Probolinggo tidak efektif. Peneliti lain yaitu Rasyid thaha (2015) juga menemukan bahwa implementasi diklatpim pola baru pada Pusdiklat Kemendagri Regional Makasar belum berjalan secara efektif. Begitu pula peneliti Harnold (2017) juga menemukan bahwa pendidikan dan pelatihan dalam meningkatkan kualitas pegawai dalam pelayanan publik di Badan Kepegawaian Daerah Kabupaten Malinau belum efektif.

Hasil penelitian di PT. BPR Bali Dananiaga menunjukkan bahwa kegiatan pendidikan dan pelatihan (diklat) yang diselenggarakan merupakan salah satu faktor untuk meningkatkan kinerja pegawai. Saat ini di PT. BPR Bali Dananiaga terus mengembangkan kompetensi di bidang pendidikan dan pelatihan (diklat) agar bisa bersaing dan tetap menjadi pilihan masyarakat. Pemberian pendidikan dan pelatihan (diklat) ini diharapkan dapat memberikan perubahan pengetahuan, ketrampilan dan sikap serta meningkatnya kinerja pegawai di PT. BPR Bali Dananiaga. Pendidikan dan pelatihan (diklat) yang akan diikuti peserta tentu harus sesuai dengan program yang telah ditetapkan instansi sesuai dengan kebutuhan, agar pemilihan peserta tidak salah, materi yang disampaikan oleh pemberi diklat pun akan sesuai, dan fasilitas penunjang pun sesuai, sehingga apa yang diperoleh oleh peserta bisa diaplikasikan ke tempat kerja masing - masing dan dapat meningkatkan kompetesinya sesuai dengan pemberian diklat. 


\section{PENUTUP}

Berdasarkan dari hasil penelitian yang dilakukan di PT. BPR Bali Dananiaga dan hasil pembahasan diatas, maka dapat disimpulkan bahwa metode pembelajaran yang di selenggarakan di PT. BPR Bali Dananiaga melalui pendidikan dan pelatihan (DIKLAT) yang telah dapatkan oleh para pegawai di PT.BPR Bali Dananiaga yang merupakan salah satu faktor untuk meningkatkan kompetensi SDM (pegawai) di bagian kredit, ini di dapat dari perubahan sikap dan perilaku serta peningkatan kemampuan, pengetahuan dan keterampilan dari pegawai yang telah mengikuti metode pembelajaran tersebut yaitu pendidikan dan pelatihan (DIKLAT) yang kemudian di aplikasikan di tempat kerja sesuai dengan bidang masing-masing, penyelesaian tugas yang dilakukan sudah tepat waktu dan sesuai dengan SOP yang telah ditetapkan perusahaan, sehingga akan terciptanya pegawai - pegawai yang berkinerja terbaik dan mempunyai potensi tinggi.

Hasil dari penulisan ini dapat dijadikan acuan oleh pimpinan PT. BPR Bali Dananiaga dalam pengambilan keputusan dan juga sebagai pedoman untuk memilih jenis pendidikan dan pelatihan (DIKLAT) yang benar - benar dibutuhkan oleh pegawai sehingga hasil dari pelaksanaan pendidikan dan pelatihan (DIKLAT) tersebut bisa diaplikasikan di tempat kerja (instansi). Hasil dari penulisan ini dapat dijadikan acuan oleh PT. BPR Bali Dananiaga dalam meningkatkan kompetensi SDM di bagian kredit khususnya tentang pelaksanaan pendidikan dan pelatihan (DIKLAT) agar dapat menghasilkan pegawai - pegawai yang berkualitas, berwawasan luas, mempunyai pengetahuan yang baik sehingga akan muncul kreativitas baru untuk memajukan perusahaan (instansi)

Dari hasil pembahasan dari bab sebelumnya dimana adanya keterbatasan pada penelitian ini, untuk itu saran bagi peneliti selanjutnya bisa lebih banyak membahas tentang jenis - jenis metode pembelajaran atau jenis - jenis pendidikan dan pelatihan (DIKLAT) dan perubahan apa yang dilakukan sehingga bisa diaplikasikan di instansi masing - masing, karena pelaksanaan pendidikan dan pelatihan (DIKLAT) bagi para pegawai merupakan kegiatan yang sangat bermanfaat bagi peningkatan kompetensi SDM. Selain itu juga untuk informan penelitian bisa ditambah dari bidang atau sub bagian lain sehingga hasil yang di peroleh nanti akan lebih baik lagi dan lebih bermanfaat untuk penelitian selanjutnya. 


\section{DAFTAR PUSTAKA}

Aditya, T. (2011). Pengaruh Kualitas Pelayanan dan Kualitas Produk Terhadap Keputusan Pembelian.

Adnyasuari, P.A.S., and Darma, G.S. (2017). Technology Acceptance Model dan ESatisfaction in Mobile Banking, Jurnal Manajemen \& Bisnis, 14 (2): 1-12.

Amstrong, M. (2006). A. HandBook, Human Resource, Management Practice, 10 the edition. London: Kogan Page.

Arsriani, I.A.I., and Darma, G.S. (2013). Peran Media Sosial Online Dan Komunitas Terhadap Keputusan Nasabah Bank, Jurnal Manajemen dan Bisnis, 10 (2): 48-68.

Ataunu, I. (2015). Pengaruh Kompetensi dan Pelatihan Terhadap Kinerja Karyawan PT. Adaro Energy TBK, Jurnal Ekonomi dan Bisnis, 16 (2).

Bali, I.N.A.P., and Darma, G.S. (2019). Menguji Kesiapan Pengelolaan Desa Berbasis Manajemen Modern Guna Menghadapi Era Revolusi Industri 4.0, Jurnal Manajemen \& Bisnis, 16 (2): 1-13.

Bangun, W. (2012). Manajemen Sumber Daya Manusia. Bandung: Erlangga.

Chrstiani, Y.T. (2013). Penerapan Balanced Scorecard Sebagai Alat Ukur Kinerja Pada PT. Bank Sulut, Jurnal EMBA 403, 1 (4): 402-413.

Darma, G.S., Wicaksono, K., Sanica, I.G., and Abiyasa, A.P. (2019). Faktor Kompensasi dan Strategi Gojek Dalam Meningkatkan Kepuasan Kerja Para Driver, Jurnal Ilmiah Manajemen Bisnis Dan Inovasi Universitas Sam Ratulangi, 6 (3): 232-244. https://doi.org/10.35794/jmbi.v6i3.27105

Darma, G.S. (2019). Kacamata Media, Kesuksesan Bersyarat. Indonesia: Pustaka Larasan Press.

Darma, G.S., Apollo, A., Rusmanda, G., and Umar, Y. (2019). Digital Education 4.0. Indonesia: Cakra Media Utama Press.

Darma, G.S. (2018). Seuntai Pesan, Menjawab Zaman. Indonesia: Pustaka Larasan Press.

Darma, G.S. (2006). Mobile Marketing: Sebuah Strategi Keunggulan Bersaing Online. Denpasar: Undiknas Press.

Darma, G.S. (2004). Qualitative and Quantitative Data in Management Research: A Study of the Banking Industry, Jurnal Ekonomi \& Bisnis, 16 (2): 107-118.

Desfian, B. (2005). Analisis Faktor-faktor Yang Berpengaruh Terhadap Kinerja Bank Umum Di Indonesia Tahun 2001-2003. Tesis Program Pasca Sarjana Magister Manajemen Universitas Diponegoro. 
Dewi, A.A.I.S., and Darma, G.S. (2017). Proses Rekrutmen, Seleksi, Pelatihan, Penempatan dan Kinerja Karyawan, Jurnal Manajemen \& Bisnis, 14 (1): 1-18.

Fadillah, R. (2017). Pengaruh Kompetensi, Disiplin Kerja dan Lingkungan Kerja Terhadap Karyawan Pada Kantor Bank Kalsel Cabang Pembantu di Banjarmasin.

Hamali, A.Y. (2016). Pemahaman Manajemen Sumber Daya Manusia. Yogyakarta: PT. Buku Seru.

Handayani, W.T., Suryono, A., Said, A. (2015) Efektivitas Pelaksanaan Pendidikan dan Pelatihan Kepemimpinan Pegawai Negeri Sipil (Studi Kasus di Badan Kepegawaian Daerah Kabupaten Probolinggo), Jurnal Administrasi Publik (JAP), 3 (5): 824-828.

Hermawan, D. (2014). Manajemen Perbankan. Jakarta: PT Bumi Aksara.

Hagos, T.M.H., \& Pal, G. (2010). The Means of analysis and Evaluation for Performances, Annales Universitatis Apulensis Series Oeconomica, 12 (1).

Harnold. (2017). Pendidikan dan pelatihan dalam meningkatkan kualitas pegawai dalam pelayanan public di Badan Kepegawaian Daerah Kabupaten Malinau, eJournal Ilmu Pemerintahan, 5 (1): 1-14.

Hunger, David, J., dan Wheelen, T.L. (2003). Manajemen Strategis. Yogyakarta: Andi.

Idham, B.F. (2013). Pengaruh Dimensi Kualitas Pelayanan Terhadap Kepuasan Nasabah Dengan Implikasi Loyalitas Pada PT.Bank Tabungan Pensiunan Nasional, TK Cabang Kertajaya Surabaya, Journal of Business and Banking, 3 (1): 93-108.

Indrawan, R., \& Yaniawan, R.P. (2016). Metodelogi Penelitian Kuantitatif, Kualitatif dan Campuran Untuk Manajemen, Pembangunan dan Pendidikan. Bandung: PT Refika Aditama. Edisi Revisi.

Juzer, J., and Darma, G.S. (2019). Strategic Supply Chain Management in the Era of Industry Revolution 4.0 : A Study of Textile Industry in Bali, Jurnal Manajemen Bisnis, 16 (3): $1-16$.

Kasmir. (2010). Dasar-dasar Perbankan. Jakarta: PT. Raja Grafindo Persada.

Kartika, L.N. (2014). Pengaruh Tingkat Kompetensi Terhadap Kinerja Pegawai Administrasi Perkantoran, Jurnal Ekonomi dan Bisnis, XVII (1).

Mangkunegara, A.A.A.P. (2012). Manajemen Sumber Daya Manusia. Bandung: PT. Remaja Rosdakarya.

Mangkunegara, AA.A.P. (2013). Manajemen Sumber Daya Manusia. Perusahaan. Bandung: PT. Remaja Rosdakarya. 
Meitaningrum, D.A., Hardjanto, I., Siswidiyanto. (2013). Efektivitas Pendidikan Dan Pelatihan Dalam Meningkatkan Kinerja Pegawai (Studi pada Badan Kepegawaian Daerah Kabupaten Malang), Jurnal Administrasi Publik (JAP), 1 (3): 192-199.

Mawardi, W. (2005). Analisis Faktor-Faktor Yang Mempengaruhi Kinerja Keuangan Bank Umum Di Indonesia (Studi Kasus Pada Bank Umum Dengan Total Assset Kurang Dari 1 Triliun), Jurnal Bisnis Strategi, 14 (1): 83-93.

Miles, M.B., \& A. Michael Huberman. (2009). Analisis Data Kualitatif. Jakarta: UI-Press.

Notoatmodjo, S. (2009). Manajemen Sumber Daya Manusia Perusahaan. Jakarta: Rineka Cipta.

Permanasari, I.A.S., and Darma, G.S. (2013). Pengaruh Penggunaan Internet Banking Terhadap Rasa Aman, Rasa Percaya Dan Loyalitas Nasabah Dalam Meningkatkan Saldo Bank, Jurnal Manajemen dan Bisnis, 10 (1): 186-204.

Premawati, I.G.A.S., and Darma, G.S. (2019). Pengaruh Ukuran Perusahaan, Pertumbuhan Penjualan, Struktur Aktiva, dan Profitabilitas Terhadap Struktur Modal (Penelitian Di Bursa Efek Indonesia Periode 2011-2015), Jurnal Ilmiah Akuntansi \& Bisnis, 2 (2): 272-286.

Rivai, V., \& Sagala, J. (2011). Manajemen Sumber Daya Manusia Untuk Perusahaan Dari Teori ke Praktik. Jakarta: Rajawali Press.

Rivai, V. (2013). Manajemen Sumber Daya Manusia Untuk Perusahaan Dari Teori Ke Praktek. Bandung: Rajagrafindo persada.

Rusmahadewi, I.A., and Darma, G.S. (2018). Team Engagement and Performance Management (A Study of Banking Industry), Jurnal Manajemen \& Bisnis, 15 (3): 3850.

Sakti, R.T., dan Mulyadi. (2015). Pelaksanaan pendidikan dan pelatihan dalam meningkatkan kinerja pegawai negeri sipil (PNS) di Dinas Pendidikan dan kebudayaan provinsi Bengkulu, Jurnal Penelitian Sosial dan Politik, 4 (2): 37-48.

Sagala, H.S. (2013). Manajemen Strategi Dalam Peningkatan Mutu Pendidikan. Cetakan keenam. Bandung: Alfabeta.

Setyani, A.Y. (2002). Analisis Kinerja Perusahaan Perbankan Sebelum dan Sesudah Menjadi Perusahaan Publik Di Bursa Efek Jakarta (BEJ). Tesis Program Pasca Sarjana Magister Akuntansi Universitas Diponegoro (tidak dipublikasikan).

Sitohang, A. (2007). Manajemen Sumber Daya Manusia. Jakarta: Pradnya Paramita. 
Thata, R. (2015). Efektivitas Implementasi Diklat Kepemimpinan Pola Baru Pada Pusat Pendidikan Dan Pelatihan Kementrian Dalam Negeri Indonesia Regional Makasar, Jurnal Administrasi Publik Volume, IX (1).

Tho'in, M. (2016). Kompetensi Sumber Daya Manusia Bank Syariah Berdasarkan PrinsipPrinsip Syariah Islam, Jurnal Ilmiah Ekonomi Islam, 02 (03).

Tridiyani, N. (2012). Pengaruh Penilaian Tingkat Kesehatan Bank Terhadap Kinerja Bank. Jakarta: Perpustakan E Journal UI.

Umar, H. (2014). Riset Sumber Daya Manusia dan Administrasi. Jakarta: Gramedia Pustaka Utama.

Utomo, I.G.W., and Darma, G.S. (2020). Measuring Optimization of Digital Military Programs: An Innovation of Information and Communication Systems in Industrial Digitalization 4.0, International Research Journal of Engineering, IT \& Scientific Research, 6 (2): 39-46. https://doi.org/10.21744/irjeis.v6n2.862

Wibowo. (2010). Manajemen Kinerja. Jakarta: Rajawali Press.

Wiandari, I.A.A., and Darma, G.S. (2017). Kepemimpinan, Total Quality Management, Perilaku Produktif Karyawan, Kinerja Karyawan dan Kinerja Perusahaan, Jurnal Manajemen \& Bisnis, 14 (2): 61-78.

Widiari, I.A.R., and Darma, G.S. (2019). Evaluasi Kinerja Pegawai Kontrak Melalui Tujuh Kompetensi Spencer Pada Pelayanan Denpasar Sewerage Development Project (DSDP), Jurnal Ilmiah Manajemen \& Bisnis, 2 (2): 360-367.

Widiastra, I.K., and Darma, G.S. (2015). Komitmen, Kepuasan Kerja, Organizational Citizenship Behavior dan Kinerja Pegawai Kontrak, Jurnal Manajemen \& Bisnis, 12 (2): $214-241$.

Yudiastra, P.P., and Darma, G.S. (2015). Pengaruh Penggunaan Teknologi Informasi, Disiplin Kerja, Insentif, Turnover Terhadap Kinerja Pegawai, Jurnal Manajemen \& Bisnis, 12 (1): 156-172. 